\title{
Effects of the Interest Rate and Reserve Requirement Ratio on Bank Risk in China: A Panel Smooth Transition Regression Approach
}

\author{
Zhongyuan Geng ${ }^{1,2}$ and Xue Zhai ${ }^{3}$ \\ ${ }^{1}$ School of Finance, Zhejiang University of Finance and Economics, Hangzhou 310018, China \\ ${ }^{2}$ Coordinated Innovation Centre of Wealth Management and Quantitative Investment, Zhejiang University of Finance and Economics, \\ Hangzhou 310018, China \\ ${ }^{3}$ The Global Banking and Markets, Hongkong and Shanghai Banking Corporation Limited, Hong Kong
}

Correspondence should be addressed to Zhongyuan Geng; zhygeng@zufe.edu.cn

Received 27 March 2015; Accepted 24 June 2015

Academic Editor: Rigoberto Medina

Copyright (C) 2015 Z. Geng and X. Zhai. This is an open access article distributed under the Creative Commons Attribution License, which permits unrestricted use, distribution, and reproduction in any medium, provided the original work is properly cited.

\begin{abstract}
This paper applies the Panel Smooth Transition Regression (PSTR) model to simulate the effects of the interest rate and reserve requirement ratio on bank risk in China. The results reveal the nonlinearity embedded in the interest rate, reserve requirement ratio, and bank risk nexus. Both the interest rate and reserve requirement ratio exert a positive impact on bank risk for the low regime and a negative impact for the high regime. The interest rate performs a significant effect while the reserve requirement ratio shows an insignificant effect on bank risk on a statistical basis for both the high and low regimes.
\end{abstract}

\section{Introduction}

Loose monetary conditions, such as low interest rates, often result in excessive credit expansion, which can largely explain the financial imbalances and economic fluctuations. Following the burst of the dotcom bubble, many central banks preferred a soft monetary policy and exerted a low interest rate over an extended period to ease the potential recessions. Continuous low interest rates can boost the increase in asset prices and securitized credit and push financial entities to take more risks [1]. It seems that bank risk is therefore increased. Although it is not the time to attribute this type of monetary policy to the 2008 global financial crisis, it may have contributed to its build-up. Thus, more and more academic and practical debates are around the effect of monetary policy on bank risk, which has become a central issue off the back of 2008 global financial crisis [2,3].

The Chinese banking system contributes the most to the financial system in China, and risks exhibited by commercial banks are the biggest threat to the nation's financial stability. The impact of monetary policy on bank risk is thus an essential issue to which should be paid great attention when establishing its macroprudential management framework. Unlike advanced economies in which standard one-instrument (a policy interest rate) operating procedure dominates the monetary policy tools, People's Bank of China (PBC, China's central bank) makes a frequent adjustment on the interest rate (a main price-based instrument) and the reserve requirement ratio (a main quantitative instrument) simultaneously to achieve its goals. During 2007-2012, People's Bank of China had adjusted the RMB 1-year benchmark deposit rate and the reserve requirement ratio for seventeen times (six times in 2007, four times in 2008, two times in 2010, three times in 2011, and two times in 2012) and thirtyfour times (ten times in 2007, nine times in 2008, six times in 2010 , seven times in 2011, and two times in 2012), respectively, which is quite uncommon in the international practice. There come some interesting questions: does interest rate and the reserve requirement ratio have different effects on the bank risk? Will it firm up the financial stability and price stability if China sticks to the frequent and simultaneous manipulation on the interest rate and the reserve requirement ratio? (About the relationship between price stability and financial stability, there are two conflicting viewpoints. One is "synergy" 
viewpoint that monetary policy aiming at price stability will be conducive to financial stability [4]. The other is "trade-off" viewpoint that monetary policy aiming at price stability is not necessarily helpful for financial stability and a trade-off relationship exists between price stability and financial stability $[5,6]$.) Is China's experience in monetary policy worth learning for other economic entities in tailoring their monetary policy? The answers of the above questions require a deep dive in the empirical test of the effects of the interest rate and the reserve requirement ratio on the bank risk in China.

A linear model has been the main focus of most research on the effect of monetary policy on bank risk, while from our perspective, monetary policy instrument delivers a nonlinear effect on bank risk due to the subjective and irrational property of bank risk behavior. The bank's risk appetite, risk perception, and risk decision-making behavior changes slowly, gradually, and continuously following the implementation of monetary policy. Moreover, different monetary policy instruments have various impacts on bank risk in terms of different macro environments and bank characteristics, which is subject to uncertainty thanks to the counteracting determinants as well. Therefore, the relationship between monetary policy instruments and bank risk follows a nonlinear path. It is much more reasonable to utilize a nonlinear model to analyze the effects of monetary policy instruments on bank risk in avoiding assumption errors and bias.

Nonlinear theories and models have matured gradually since the 1970s, which sparks scholars in accepting the fact that nonlinear model can fit economic phenomena and economic laws in a better manner [7]. Among multiple available nonlinear models, regime-switching models are the most popular ones. Common nonlinear regime-switching models include the following three models: Markov regimeswitching (MRS) model, threshold regression (TR) model, and smooth transition regression (STR) model. MRS and TR models are based on the assumption that the transition from one regime to anther is discrete, which is inconsistent with the reality in many cases, and thus limits their application in practice. Hansen [8] made an initial effort on introducing threshold effects, together with a panel threshold regression (PTR) model which assumes a jumping transition through different regimes. In improving the practicability, González et al. [9] developed the Panel Smooth Transition Regression (PSTR) model, extending a smooth transition regression (STR) model to panel data heterogeneity across the panel members and over time [10]. The merged PSTR version of combining both STR and panel data enables the transition to switch between regimes over time as smooth as it can be.

This paper utilizes a PSTR model to study the nonlinearity between monetary policy instruments (i.e., the interest rate and the reserve requirement ratio) and bank risk. Our study differs from the previous literature in the following ways. First, in the PSTR model established for the analysis of effects of the interest rate and the reserve requirement ratio on bank risk, the empirical results indicate that the interest rate and the reserve requirement ratio have nonlinear impacts on bank risk. Second, the result demonstrates that the objective function of the central bank should be nonlinear-oriented and bring in financial sector. The standard textbook approach adopts a linear-quadratic (LQ) framework in analyzing optimal monetary policy, where the dynamic behavior of the economy is described as linear and the objective function stressing the policy goals is quadratic. Monetary policy is always keeping a balance by seeking an optimal match point at which the loss function is minimized and the squared value of the inflation gap and the squared value of the output gap are comprised at the same time [11]. Our empirical results give evidence to the fact that monetary policy instruments produce nonlinear effects on bank risk. In that case, the central bank should incorporate nonlinear elements and a financial stability variable into its objective function. Third, we try to differentiate the effects of the interest rate and the reserve requirement ratio on bank risks, thereby providing comprehensive policy guidance in China's implementation. Additionally, some useful information can be dug up from the result as well facilitating the policymakers of other countries in designing their monetary policy.

The remainder of the paper is organized as follows: Section 2 reviews the literatures. Section 3 sketches out the general empirical model to be estimated and describes the data. Section 4 presents the empirical results and related comments. Section 5 provides the conclusive remarks.

\section{Literature Review}

The effects of monetary policy on bank risk are a part of, although distinguishable from, the relationship between monetary policy and financial stability which is detailed by Oosterloo and de Haan [12] and is not discussed here. So far, there is very limited theoretical support and empirical evidence about the effects of monetary policy on bank risk [1].

Advanced economies typically use a policy interest rate as the monetary policy instrument. So, the studies on the effects of monetary policy on bank risk concentrate on the effects of interest rate on bank risk. The theoretical research in the literature suggests several channels that interest rate affects bank risk [13, 14]: (1) "Asset valuation" channel: A reduction in the interest rate boosts asset and collateral values, which in turn can modify banks' estimation of probabilities of default, loss given default, and volatilities, and it incents banks to take on risk. (2) "Search for yield" channel: Low interest rates cause banks' target revenue to decline, which provokes banks to invest in high-margin and high-risk areas or financial instruments. (3) "Asset substitution" channel: The decline in interest rates will lead to a low proportion of safe assets in the bank assets portfolio. Risk-neutral banks will increase the demand for risky assets until a new equilibrium arises in the ratio of safe assets and risky assets. (4) "Constant leverage" channel: Commercial banks target a constant leverage ratio. Low interest rates will boost the assets prices. Bank equity will increase and banks will respond to the fall in leverage by increasing their demand for risky assets. This reaction reinforces the initial boost to asset values, and so on. The result is a more fragile banking system that is more exposed to negative shocks to asset values and thus riskier. (5) "Central bank communication" channel: If the central bank has transparent policy and credible commitment, low interest rate is an implicit commitment that will induce collective 
moral hazard. Low interest rates mean loose monetary and regulatory environment, which stimulates banks to take on more risk. (6) "Asset-liability mismatch" channel: When interest rates are low, banks can only absorb short-term deposits. The mismatch between short-term deposits and long-term project finance tends to high leverage. The more leveraged the banks are, the higher the risk of failure is. (7) "Habit formation" channel: If the interest rate is low, investors tend to consume more and the expected credit spread is high. Thus, investors are willing and able to get more loans from the bank or invest in high-risk financial instruments, which results in higher bank risk. In addition, some studies suggest that interest rates have an uncertain effect on bank risk, which depends on many factors that affect the mutually countervailing forces [1]. The effect of changes in interest rates on bank risk may change over time, along with a change in the banking system or a change in the characteristics of the bank itself [15].

Empirical research shows some conflicting findings. One such finding claims that low interest rates lead to an increase in bank risk and high interest rates can prevent its accumulation [16-19], while others $[20,21]$ claim that the reverse is true. Interestingly, Thakor [22], Jiménez et al. [23], and Martha López et al. [24] document an uncertain effect of interest rates on bank risk. Interest rates have a smaller impact on the risky assets of banks with higher capital, but a larger effect on the banks with more off-balance business. Certain banks can react heterogeneously to interest rate changes. Banks with a high capital adequacy rate and income diversification perform more radically in their risk-taking.

Some observation can be noted from the literature cited above. First, most of the previous studies have employed the ordinary least squares and generalized least squares methodology to establish a linear model to study the impact of monetary policy on bank risk in the context of cross-sectional or time series. Yener et al. [25] studied the nonlinear effects of monetary policy on bank risk by simply incorporating the quadratic term of an explanatory variable-credit expansion into the linear regression equation, without establishing a cutting-edge nonlinear model. Second, few studies compare the different effects of the interest rate and the reserve requirement ratio on bank risk. In advanced economies, interest rate is the major monetary policy instrument. Thus, they focus primarily on the effect of interest rates on bank risk. In China, some scholars concentrate on the effects of the interest rate and the reserve requirement ratio on bank risk, but they all draw the same conclusion that both the interest rate and the reserve requirement ratio have a negative effect on bank risk $[26,27]$.

\section{Model Specification and Data}

When the sample size is not sufficiently large, the introduction of too many explanatory variables will result in the decline in the degrees of freedom and multicollinearity. Therefore, this study will only concentrate on the impact of macroeconomic factors on bank risk and does not consider effects of the bank-level micro factors on bank risk. From the angle of monetary policy instruments, we construct the following PSTR model to study the effects of interest rate and reserve requirement ratio on the bank risk (about the detailed methodology of PSTR model, see Granger and Teräsvirta [28], Teräsvirta [29], Eitrheim and Teräsvirta [30], Hansen [8], and González et al. [9]). Consider

$$
\begin{aligned}
\mathrm{EDF}_{i, t}= & \mu_{i}+\beta_{0} \mathrm{IR}_{i, t}+\beta_{1} H_{i, t}+\left(\beta_{0}^{\prime} \mathrm{IR}_{i, t}+\beta_{1}^{\prime} H_{i, t}\right) \\
& \cdot g\left(P_{i, t} ; \gamma, c\right)+\varepsilon_{i, t}, \\
\mathrm{EDF}_{i, t}= & \mu_{i}+\beta_{0} \mathrm{RR}_{i, t}+\beta_{1} H_{i, t}+\left(\beta_{0}^{\prime} \mathrm{RR}_{i, t}+\beta_{1}^{\prime} H_{i, t}\right) \\
& \cdot g\left(P_{i, t} ; \gamma, c\right)+\varepsilon_{i, t},
\end{aligned}
$$

where $i=1, \ldots, N, t=1, \ldots, T$, and $N$ and $T$ denote the cross section and time-dimension of the panel, respectively. $\mathrm{EDF}_{i, t}=$ expected default frequency, which is the dependent variable, $\mu_{i}$ represents the fixed effects, $\mathrm{IR}_{i, t}=$ interest rate; $\mathrm{RR}_{i, t}=$ reserve requirement ratio; $H_{i, t}=$ real estate price index; $P_{i, t}=$ purchasing managers' index, a threshold variable. The $g$ is the transition functions, normalized to be bounded between 0 and 1. (When the transition function equals 0 or 1 , the corresponding model is, resp., called low regime or high regime. The values of transition function transit between 0 and 1 smoothly, which makes the model transit between low regime and high regime smoothly.) $\gamma$ slope parameter denotes the speed of transition from one regime to the other, $c$ the threshold parameters, $\varepsilon$ the residual term, and $\beta$ the regression coefficients.

Before carrying out the empirical analysis, we should discuss the variables used and the dataset. In view of the availability of the data, we use the quarterly (from 04/2007 to $03 / 2012$ ) data of thirteen Chinese listed banks. (The data of listed banks is from the $A$ share market rather than $H$ share market. We exclude Agricultural Bank of China, China Everbright Bank, and China Construction Bank. The reasons are as follows. Agricultural Bank of China and China Everbright Bank became a listed bank in 2010 and there is not much data available. In December 2011, the number of total shares, $A$ shares, and $H$-shares of China Construction Bank is, resp., 250.01 billion, 9.593 billion, and 214.83 billion. The ratio of $A$ shares to total shares is only $3.84 \%$, producing the mismatch between $A$ share market value (too less) and liabilities (too more). This mismatch will result in the fact that calculated value of EDF cannot objectively reflect the expected default frequency of China Construction Bank.) Considering that the calculation of EDF requires bank's stock returns and market value data which can be present only after the bank lists and that the Bank of Communications, the Industrial Bank, the CITIC Bank, the Bank of Ningbo, the Bank of Nanjing, and the Bank of Beijing became listed banks in 2007, our sample starts from the fourth quarter of 2007 so as to obtain sample data as much as possible. The sample contains three large commercial banks, seven joint-stock commercial banks, and three city commercial banks. Among those, the large commercial banks include the Industrial and Commercial Bank of China (ICBC), the Bank of China (BOC), and the Bank of Communications (BOCOM); the joint-stock commercial banks include CITIC 
Bank, Huaxia Bank (HB), Pingan Bank (PB), China Merchants Bank (CMB), Shanghai Pudong Development Bank (SPDB), Industrial Bank (IB), and China Minsheng Banking Co. (CMSB); the city commercial banks include Beijing Bank (BB), Nanjing Bank (NJB), and Ningbo Bank (NBB).

Table 1 provides descriptive statistics for the variables used in the empirical analysis. Table 2 reports correlation coefficients between these variables. According to Gujarati Damodar [31], if the zero-order correlation coefficient of two regressors is over 0.8 , the multicollinearity problem will be severe. Correlations in our study are at acceptable levels as shown in Table 2.

In what follows, we analyze the choice of the dependent, explanatory, transition, and control variables.

3.1. Bank Risk. As for the dependent variable measuring bank risk, we chose the expected default frequency (EDF). This indicator has become a popular measure of bank soundness in related empirical work on financial stability. Theoretically, according to the nature of the risk, EDF that utilizes stock price and earnings volatility to characterize the risk behaviour of the bank is undoubtedly the ideal choice [25]. The reasons are listed below. First, EDF is relatively objective because it is calculated on the basis of stock transaction data and financial data found in the financial statements of the listed banks. Second, EDF is a dynamic index and can be updated based on changes of stock transaction data and regularly published financial statements of listed banks. Therefore, EDF can reflect changes of bank risk over time. Third, EDF overcomes the bias caused by applying historical data to represent future trends. EDF is calculated on the basis of real-time situations of the stock market. Changes of the yields and market value in the stock market can reflect the bank's performance, market expectations, and future trends.

EDFs are the outcome of Moody's KMV model which establishes a functional relationship between distance to default and the probability of default. The EDF of a company varies over time, reflecting the changing economic prosperity of the firm or its industry sector. A detailed description of the mapping between the distance to default and the EDF measure can also refer to Crouhy et al. [32].

We use the method of Brandimarte [33] to calculate the EDF. Results of EDF calculations by Matlab7.0 software are reported in Table 3 . The risk-free interest rate needs to be used to calculate EDF and it is based on the daily weighted average of the RMB 1-year benchmark deposit rate. (The following data is from RESSET Financial Research Database and RESSET is China's leading provider of financial databases: thirteen listed banks' daily yield, daily total market value, quarterly long-term liabilities, and quarterly shortterm liabilities that are used to calculate EDF; broad money; quarterly real estate price index; RMB 1-year benchmark deposit rate. The data of purchasing manager's index (PMI) is derived from CEInet statistics database (CEI: China Economic Information).)

3.2. Monetary Policy Instruments. About monetary policy instruments, we choose the reserve requirement ratio (a main quantitative instrument) and interest rate (a price-based
TABLE 1: Descriptive statistics.

\begin{tabular}{lcccc}
\hline Variable & Mean & Standard deviation & Minimum & Maximum \\
\hline EDF & 0.011 & 0.064 & $4.351 E-22$ & 0.810 \\
IR & 0.030 & 0.007 & 0.023 & 0.041 \\
RR & 0.176 & 0.024 & 0.131 & 0.215 \\
$P$ & 52.007 & 3.144 & 42.118 & 56.504 \\
$H$ & 103.816 & 6.186 & 91.072 & 111.510 \\
\hline
\end{tabular}

TABLE 2: Correlations.

\begin{tabular}{lcccc}
\hline & IR & RR & $P$ & $H$ \\
\hline IR & 1 & & & \\
RR & & 1 & & \\
$P$ & -0.164 & -0.344 & 1 & \\
$H$ & -0.023 & -0.547 & 0.517 & 1 \\
\hline
\end{tabular}

instrument), because they are two main policy instruments applied by People's Bank of China (PBC, China's central bank).

We adopt the reserve requirement ratio for the large financial institutions (denoted by RR) with the reason that large financial institutions are the majority of Chinese banking industry and the reserve requirement ratios for the large, small, and medium-sized financial institutions have a basically uniform trend.

The interest rate, IR, is denoted by the RMB 1-year benchmark deposit rate rather than the RMB 1-year benchmark loan rate, because the former is mainly set by the PBC and the latter can float greatly according to the will of commercial banks and cannot fully be controlled by the PBC.

Since the reserve requirement ratio and the RMB 1-year benchmark deposit rate may be changed for several times within one quarter or one year, the daily weighed means of both is used.

3.3. Transition Variable. The purchasing manager's index (PMI), denoted as $P$, measures the macroeconomic boom or bust. As an indicator of the economic health of the manufacturing sector, purchasing manager's index (PMI) is well known and widely used in the world. The PMI is based on the key indicators: new orders, inventory levels, production, supplier deliveries, and the employment environment. A PMI of more than 50 represents expansion in business activity, compared with the previous month. A reading under 50 represents a contraction, while a reading at 50 indicates no change. The PMI is usually released at the start of the month, much before most of the official data on industrial output, manufacturing, and GDP growth becomes available. It is, therefore, considered as a good leading indicator of economic activity. It is reasonable for us to use the PMI with the reason that China is a big manufacturing country and the boom and bust of manufacturing can be representative of the macroeconomic cycle.

We choose the PMI as a transition variable, with the aim of studying the effect of monetary policy in different macroeconomic situations on bank risk. 


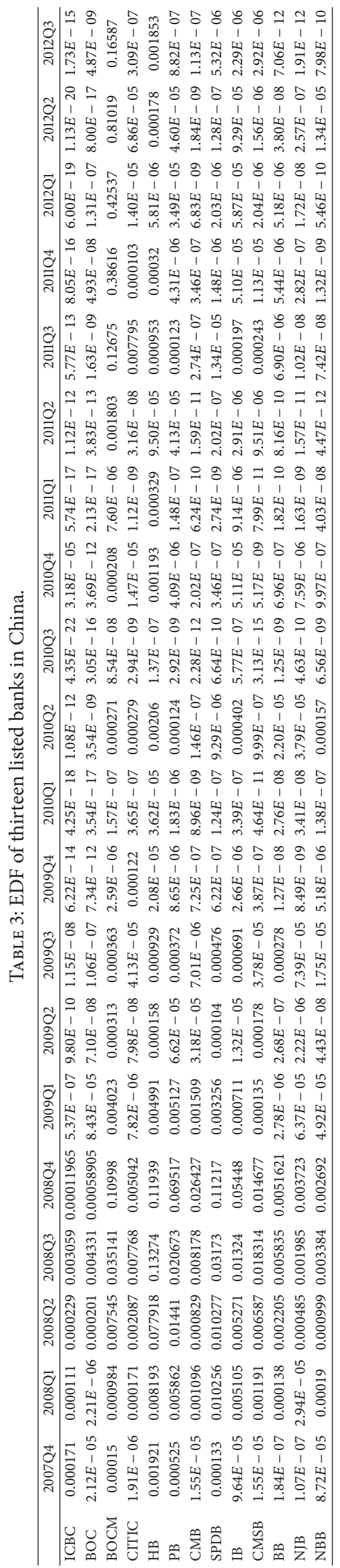


3.4. Control Variable. In recent years, the real estate market has been hot and real estate loans have accounted for a significant portion of bank credit in China, introducing potential risk. We select the real estate price index, represented by $H$, as a control variable to reflect the effect of the real estate market on the risk of banks.

\section{Results and Analysis}

4.1. Linearity and No Remaining Nonlinearity Results. The results of the linearity tests are presented in Table 4 and show that the null hypotheses, that model (1) and model (2) are both linear, are rejected at the 5\% significance level for the Wald test, implying that the relationship between interest rate, reserve requirement ratio, and bank risk is indeed nonlinear. Table 5 presents the test for no remaining nonlinearity after assuming a two-regime model. The results indicate that the null hypothesis cannot be rejected, implying that model (1) and model (2) have both only one threshold or two regimes. This implies that there is only one threshold level of interest rate or reserve requirement ratio which separates the low and high money supply regimes in model (1) or model (2).

4.2. Model Estimation Results. We utilize the nonlinear least squares method to estimate parameters. Before the estimation of the parameter, we should apply the grid search method to determine the initial value of the transition speed $(\gamma)$ and location parameters $(c)$. The higher the number of iterations is, the better the initial value is. For accuracy and time-saving reason, the number of iterations is set as 20,000. Estimated model (1) and model (2) parameters are presented in Table 6.

4.2.1. Model (1). This is a two-regime PSTR model, the transition speed is positive and low, and the location parameter (48.748) is within the changing interval of transition variable (PMI). When the PMI is over 48.748, the model gradually moves towards the high regime with an increasing transition variable. When the PMI is under 48.748 , the model gradually falls to a low regime with the decrease of the transition variable. The effects of interest rate on bank risk transit smoothly and gradually between the high and low regimes with the change in the value of the transition variable. Within the time interval of 20 quarters: the PMI is solely under the location parameter in the fourth quarter of 2008, while in the remaining quarters, the PMI exceeds the location parameter. This shows that PMI affects bank risk mainly in the high regime.

Coefficient for the interest rate is statistically significant and positive for the low regime $\left(\beta_{0}\right)$ and statistically significant and negative for the high regime $\left(\beta_{0}+\beta_{0}^{\prime}\right)$. This indicates that when PMI is under 48.748 , interest rate has a positive effect on bank risk and when PMI is above 48.748, interest rate is negatively correlated with bank risk. The probable reasons are as follows. When PMI is under 48.748, the central bank will reduce the interest rate to stimulate the economy, which means there is a down economy. In this case, the banks are cautious and dare not be involved in the highly risky field
TABLE 4: Linearity tests.

\begin{tabular}{lccc}
\hline & Test & Statistic & $P$ value \\
\hline Model (1) & Lagrange multiplier-Wald & 15.221 & 0.048 \\
Model (2) & Lagrange multiplier-Wald & 19.489 & 0.026 \\
\hline
\end{tabular}

Note: $H_{0}$ : linear model; $H_{1}$ : PSTR model with at least one threshold.

TABLE 5: Tests of no remaining nonlinearity (test for the number of regimes).

\begin{tabular}{lccc}
\hline & Test & Statistic & $P$ value \\
\hline Model (1) & Lagrange multiplier-Wald & 0.017 & 0.992 \\
Model (2) & Lagrange multiplier-Wald & 0.047 & 0.977 \\
\hline
\end{tabular}

Note: $H_{0}$ : PSTR with one threshold; $H_{1}$ : PSTR with at least two thresholds.

TABLE 6: PSTR models estimation. Dependent variable: EDF.

\begin{tabular}{lcc}
\hline Parameters & Model $(1)$ & Model $(2)$ \\
\hline$\beta_{0}$ & $6.075^{* * *}(2.340)$ & $3.480(1.346)$ \\
$\beta_{1}$ & $-0.003(-1.587)$ & $-0.006(-1.220)$ \\
$\beta_{0}^{\prime}$ & $-6.089^{* * *}(-2.164)$ & $-3.595(-1.284)$ \\
$\beta_{1}^{\prime}$ & $0.002^{* *}(1.771)$ & $0.006(1.202)$ \\
$\gamma$ & 0.483 & 0.515 \\
$c$ & 48.748 & 47.152 \\
RSS & 0.827 & 0.835 \\
\hline
\end{tabular}

Note: the values in parentheses are $t$-statistics. $* * * / * *$ denote significance at the $1 \%$ and $10 \%$ levels, respectively.

or business and the bank risk is low. PMI above 48.748 shows that there will be an up economy; the central bank tends to increase the interest rate to suppress the probable economic overheating. In our sample period, RMB 1-year benchmark deposit rate and ROE (Return on Equity) of the banks are positively correlated (their correlation coefficient is 0.101 ). In this case, RMB 1-year benchmark deposit rate is high and the banks also have a high profit. Thus, the banks do not take more risk to make a lot of profit. Therefore, bank risk is low.

4.2.2. Model (2). This is also a two-regime PSTR model, the transition speed is positive and low, and the location parameter (47.152) is within the changing interval to transition variable (PMI). When the PMI is over 47.152, the model gradually moves closer to the high regime with an increasing transition variable. When the PMI is under 47.152, the model gradually falls to a low regime with the decrease of the transition variable. The effects of the reserve requirement ratio on bank risk transit smoothly and gradually between the high and low regimes with the change in the value of the transition variable. Within the time interval of 20 quarters: the PMI is under the location parameter only in the fourth quarter of 2008, while in the remaining quarters, the PMI exceeds the location parameter. This shows that the reserve requirement ratio affects bank risk mainly in the high regime.

Coefficient for the reserve requirement ratio is positive for the low regime $\left(\beta_{0}\right)$ and negative for the high regime $\left(\beta_{0}+\beta_{0}^{\prime}\right)$ but is statistically insignificant in both regimes. 
To sum up, if the transition variable is the PMI, the interest rate has a significant effect while the reserve requirement ratio has an insignificant effect on bank risk in China.

\section{Concluding Remarks}

We adopted the Panel Smooth Transition Regression (PSTR) approach to analyse the effects of the interest rate and the reserve requirement ratio on bank risk empirically, based upon the Chinese bank quarterly data from 04/2007 to $03 / 2012$. The outcome of the exercise evidenced the nonlinear nexus between monetary policy instruments and bank risk, which was assumed by the utilized model. Our findings manifest that the consecutive change in the value of the PMI threshold level enables the impact of the interest rate and the reserve of requirement ratio on bank risk to undertake a smooth and gradual transition from high to low regime. The interest rate has a positive and statistically significant effect on bank risk for the low regime and a negative and statistically significant effect for the high regime. The effects of the reserve requirement ratio on bank risk are positive and statistically insignificant in low regime and negative and statistically insignificant in high regime.

The empirical results deliver theoretical implication and practical significance. It should improve upon the standard textbook approach to analyzing optimal monetary policy, the linear-quadratic (LQ) framework only focusing on output and inflation rather than financial stability. The reaction function of monetary authorities should seek a way to involve nonlinear effects as well as financial sector in the macroeconomic decision-making model.

In achieving financial stability and monetary policy effectiveness, the monetary authorities should concentrate on the nonlinear effects of the interest rate on bank risk in both the high and low regimes of PMI. Strengthened macroprudential supervision and active cooperation with regulatory authorities aid attention in bank risk monitoring and research to avoid any potential risk against financial imbalances. Finally, commercial banks should devise an enhanced early risk-warning system, which is incorporated with the nonlinear effects of the interest rate on bank risk in both the high and low regimes of the PMI.

Our empirical results can make helpful suggestion to policymakers in China and other countries in monetary policy formulation. The empirical results mean the interest rate has a significant effect (positive in a low regime and negative in a high regime) while the reserve requirement ratio has an insignificant effect on bank risk in China. Therefore, applying the interest rate and the reserve requirement ratio on a frequent and controllable basis is flexible for China to realize financial and price stability. For example, when the economy is down, the central bank can cut the interest rate or (and) the reserve requirement ratio to stimulate the economy and make the price level upward, without being afraid of the adverse effects of the interest rate and the reserve requirement ratio on the bank risk with the reason that the former has a significant and positive effect and the latter has an insignificant effect on bank risk. When the economy is up, the central bank will increase the interest rate or (and) the reserve requirement ratio to suppress the economy and make the price level downward, without being afraid of the adverse effects of the interest rate and the reserve requirement ratio on the bank risk with the reason that the former has a significant and negative effect and the latter has an insignificant effect on bank risk.

\section{Conflict of Interests}

The authors declare that there is no conflict of interests regarding the publication of this paper.

\section{Acknowledgments}

The authors acknowledge the financial support of the National Natural Science Foundation of China (Grant no. 71103048 and Grant no. 71273224) and the State Scholarship Fund of the China Scholarship Council (File no. 201203070348). Thanks are due to Shangwei Fan (Passport no. G52596733) for helping the authors collect and sort the data.

\section{References}

[1] G. De Nicolò, G. Dell'Ariccia, L. Laeven, and F. Valencia, "Monetary policy and bank risk taking," IMF Staff Position Notes SPN/10/09, International Monetary Fund Home, 2010.

[2] Z. Chang, "Liquidity shocks, monetary policy mistakes and financial crisis-a reflection of the U.S. financial crisis," Journal of Financial Research, vol. 7, pp. 18-33, 2010 (Chinese).

[3] M. Hongxia and S. Xuefen, "Academic debate on the financial crisis and monetary policy," Economic Perspectives, vol. 8, pp. 119-124, 2010 (Chinese).

[4] A. Schwartz, "Systemic risk and the macroeconomy," in Banking Financial Markets and Systemic Risk, G. Kaufman, Ed., vol. 7 of Research in Financial Services, Private and Public Policy, pp. 1930, JAI Press, 1995.

[5] C. Borio and P. Lowe, "Asset prices, financial and monetary stability: exploring the nexus," BIS Working Papers 114, BIS, 2002.

[6] G. J. Schinasi, "Responsibility of central banks for stability in financial markets," IMF Working Paper WP/03/121, 2003.

[7] Z. Chang, "Application of nonlinear dynamics in the field of macroeconomics: a survey," Economic Research Journal, vol. 9, pp. 117-128, 2006 (Chinese).

[8] B. E. Hansen, "Threshold effects in non-dynamic panels: estimation, testing, and inference," Journal of Econometrics, vol. 93, no. 2, pp. 345-368, 1999.

[9] A. González, T. Teräsvirta, and D. van Dijk, "Panel smooth transition regression models," Research Paper 165, Quantitative Finance Research Centre, University of Technology, Sidney, Australia, 2005.

[10] T. Chang and G. Chiang, "Regime-switching effects of debt on real GDP per capita the case of Latin American and Caribbean countries," Economic Modelling, vol. 28, no. 6, pp. 2404-2408, 2011.

[11] F. S. Mishkin, "Monetary policy flexibility, risk management, and financial disruptions," Journal of Asian Economics, vol. 21, no. 3, pp. 242-246, 2010. 
[12] S. Oosterloo and J. de Haan, "Central banks and financial stability: a survey," Journal of Financial Stability, vol. 1, no. 2, pp. 257-273, 2005.

[13] T. Adrian and H. S. Shin, "Money, liquidity, and monetary policy," American Economic Review, vol. 99, no. 2, pp. 600-605, 2009.

[14] C. Borio and H. Zhu, "Capital regulation, risk-taking and monetary policy: a missing link in the transmission mechanism?" Journal of Financial Stability, vol. 8, no. 4, pp. 236-251, 2012.

[15] G. Dell'Ariccia, L. Laeven, and R. Marquez, "Real interest rates, leverage, and bank risk-taking," Journal of Economic Theory, vol. 149, pp. 65-99, 2014.

[16] A. Maddaloni and J.-L. Peydró, "Bank risk-taking, securitization, supervision, and low interest rates: evidence from the Euro-area and the U.S. lending standards," Review of Financial Studies, vol. 24, no. 6, pp. 2121-2165, 2011.

[17] V. Ioannidou, S. Ongena, and J.-L. Peydro, "Monetary policy, risk-taking and pricing: evidence from a quasi-natural experiment," The Review of Finance, vol. 19, no. 1, pp. 95-114, 2014.

[18] M. D. Delis and G. P. Kouretas, "Interest rates and bank risktaking," Journal of Banking \& Finance, vol. 35, no. 4, pp. 840855, 2011.

[19] Y. Yu and W. He, "Empirical test of monetary policy, credit quality and bank risk appetite," Studies of International Finance, vol. 12, pp. 59-68, 2011 (Chinese).

[20] M. Lucchetta, "What do data say about monetary policy, bank liquidity and bank risk taking?” Economic Notes, vol. 36, no. 2, pp. 189-203, 2007.

[21] T. Zhong and S. Fang, "Empirical analysis of monetary policy, market discipline and bank risk taking behaviour," Journal of Shanghai University of Finance and Economics, vol. 11, pp. 5765, 2011 (Chinese).

[22] A. V. Thakor, "Capital requirements, monetary policy, and aggregate bank lending: theory and empirical evidence," Journal of Finance, vol. 51, no. 1, pp. 279-324, 1996.

[23] G. Jiménez, S. Ongena, J.-L. Peydró, and J. Saurina, "Hazardous times for monetary policy: what do twenty-three million bank loans say about the effects of monetary policy on credit risktaking?” Econometrica, vol. 82, no. 2, pp. 463-505, 2014.

[24] P. Martha López, G. Fernando Tenjo, and S. Hector Zárate, “The risk-taking channel and monetary transmission mechanism in Colombia," Borradores de Economia 616, Banco de la Republica de Colombia, 2010.

[25] A. Yener, L. Gambacorta, and D. Marquez-Ibañez, "Does monetary policy affect bank risk-taking?” Working Paper 1166, European Central Bank, 2010.

[26] J. Shuxia and C. Yuchan, "Monetary policy, bank capital and risk-taking," Journal of Financial Research, no. 4, pp. 1-15, 2012 (Chinese).

[27] F. Yi, Z. Shengmin, and X. Xiaowen, "An analysis of bearing bank risks in monetary policies: on the coordination between the monetary policy and the macro-prudential policy," Management World, no. 11, pp. 9-19, 2012 (Chinese).

[28] C. Granger and T. Teräsvirta, Modelling Nonlinear Economic Relationships, Oxford University Press, New York, NY, USA, 1993.

[29] T. Teräsvirta, "Specification, estimation and evaluation of smooth transition autoregressive models," Journal of the American Statistical Association, vol. 89, no. 425, pp. 208-218, 1994.

[30] Ø. Eitrheim and T. Teräsvirta, "Testing the adequacy of smooth transition autoregressive models," Journal of Econometrics, vol. 74, no. 1, pp. 59-75, 1996.
[31] N. Gujarati Damodar, Basic Econometrics, China Renmin University Press, Beijing, China, 3rd edition, 2000.

[32] M. Crouhy, D. Galai, and R. Mark, Risk Management, McGrawHill, New York, NY, USA, 2001.

[33] P. Brandimarte, Numerical Methods in Finance and Economics: A MATLAB-Based Introduction, John Wiley \& Sons, New York, NY, USA, 2006. 


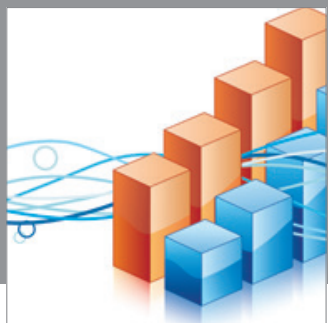

Advances in

Operations Research

mansans

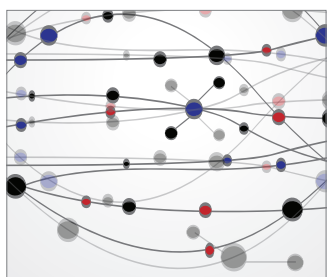

The Scientific World Journal
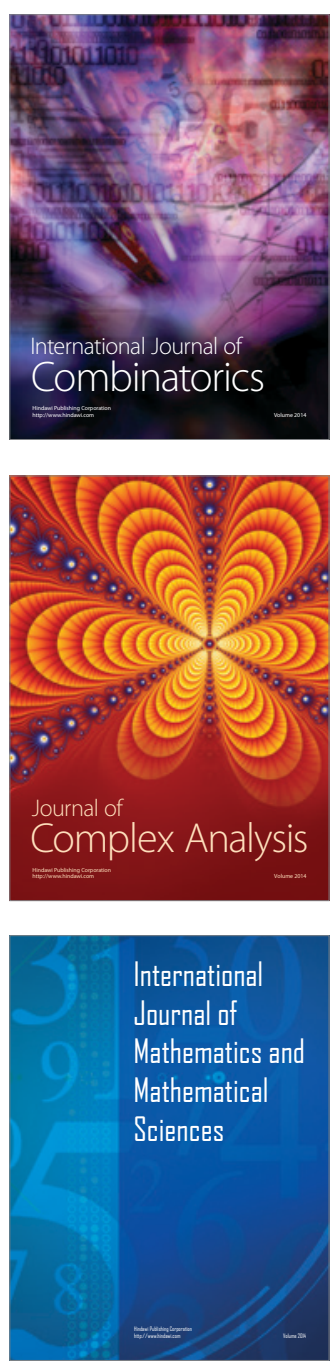
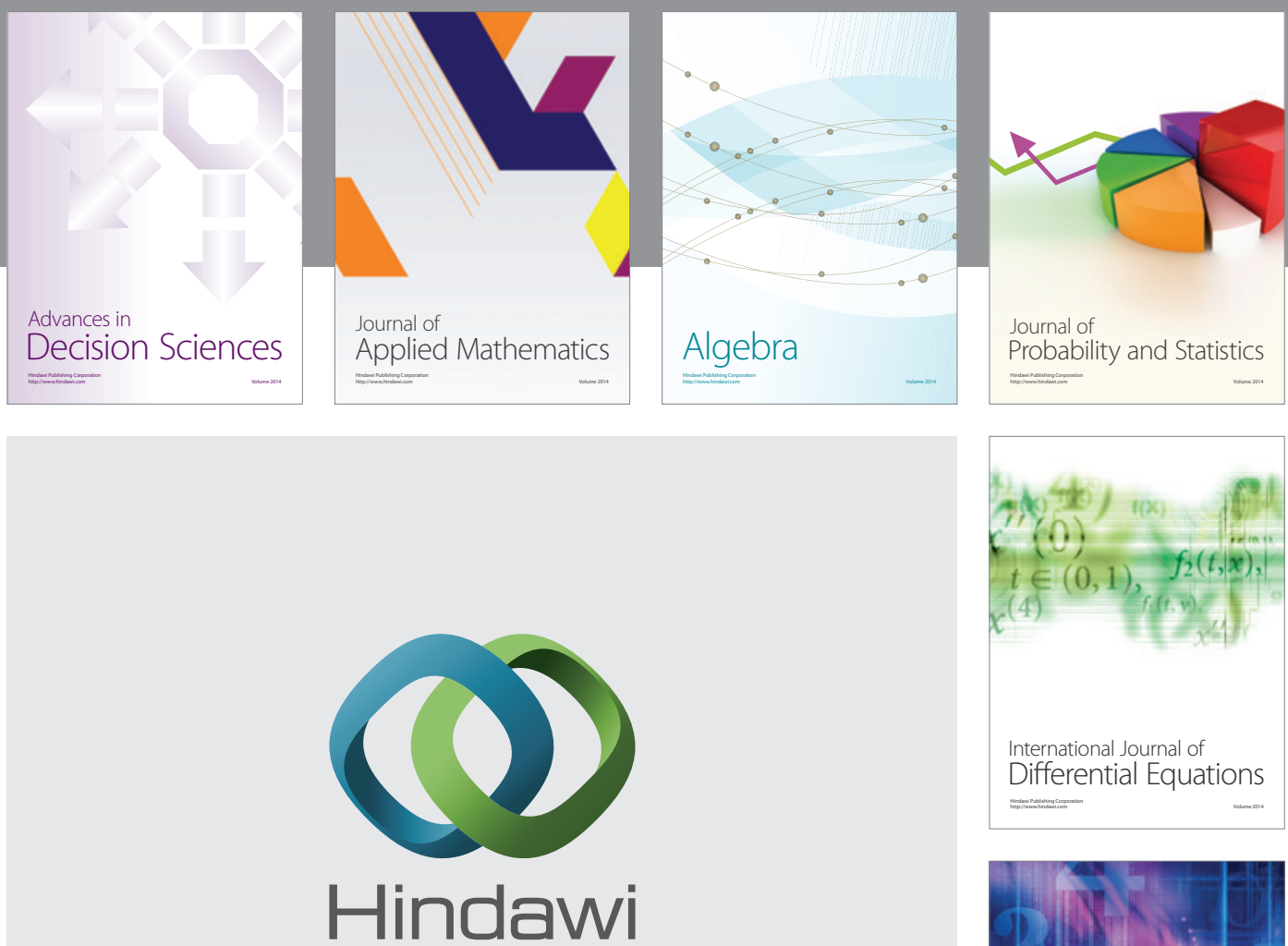

Submit your manuscripts at http://www.hindawi.com
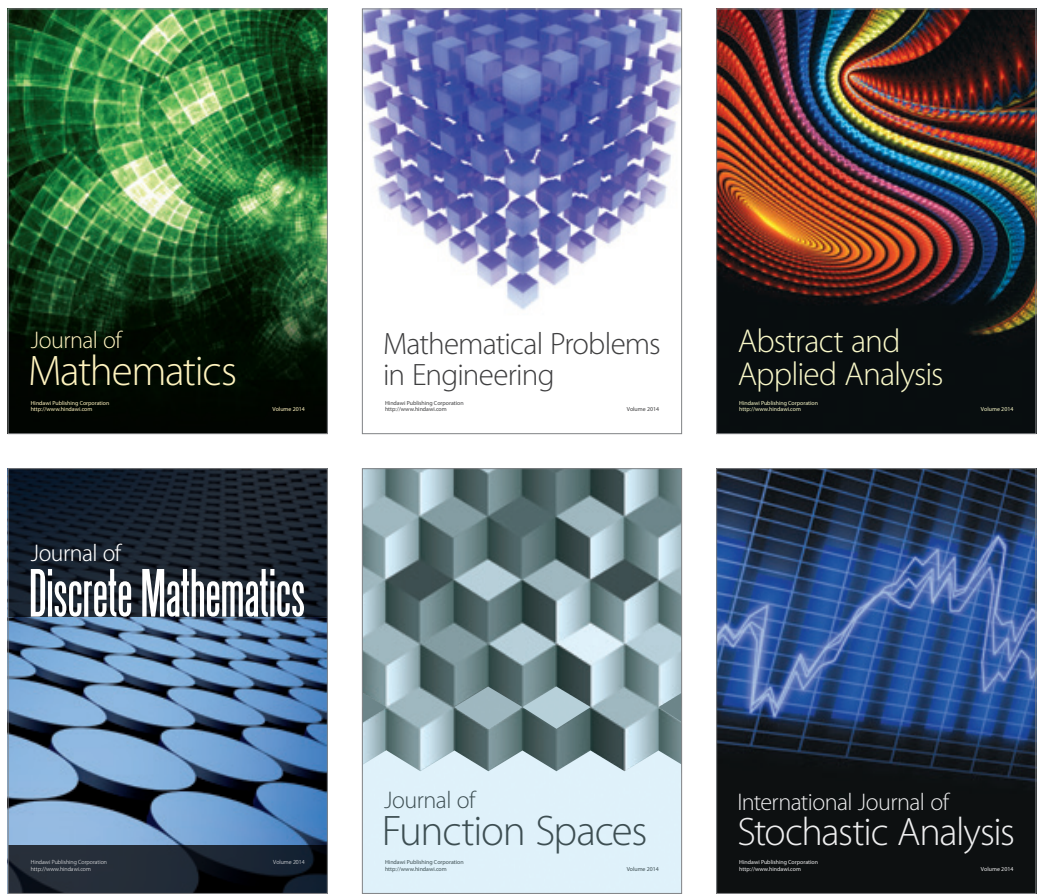

Journal of

Function Spaces

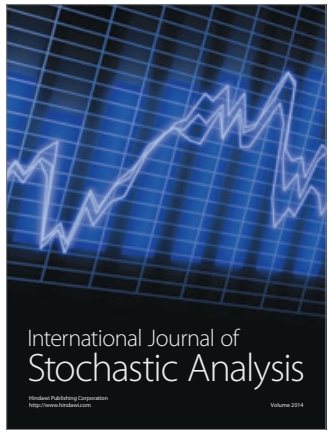

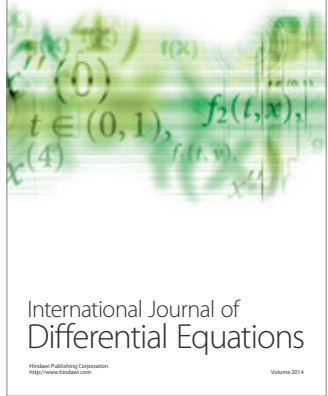
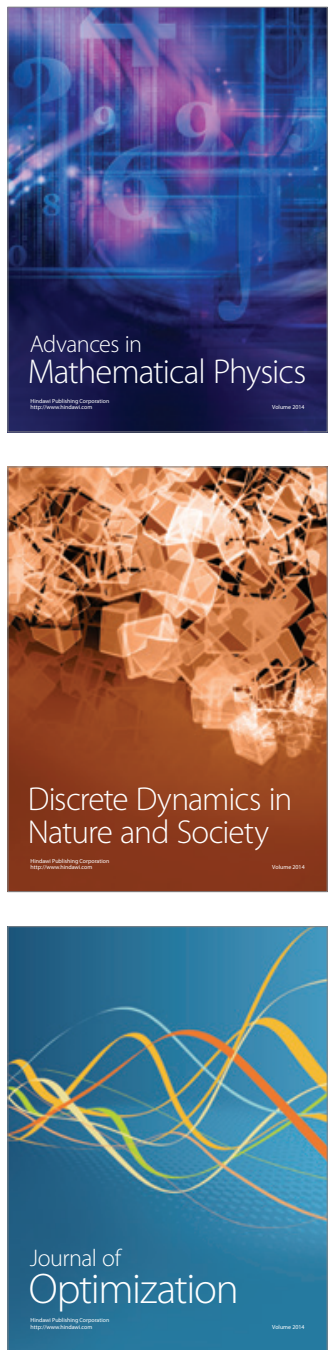